\title{
Analgesic Activity of Conyza Floribunda Extracts in Swiss Albino Mice
}

\author{
Sylvia A. Opiyo ${ }^{1 *} \quad$ Kennedy K. Muna $^{2} \quad$ Peter W. Njoroge ${ }^{1} \quad$ Ephantus G. Ndirangu $^{1}$ \\ 1.Department of Physical and Biological Sciences, Murang'a University of Technology, \\ P.O. Box 75-10200, Murang'a, Kenya \\ 2.Department of Medical Laboratory Science, Murang'a University of Technology, Box 75-10200, Murang'a, \\ Kenya \\ *E-mail: sylvopiyo@yahoo.com; sopiyo@mut.ac.ke
}

\begin{abstract}
Traditional medicine still plays an important role in managing infections especially in Africa. Extracts of Conyza floribunda Kunth are used to treat sore throat, ringworm and other skin related infections, toothache and to stop bleeding from injuries. Extracts from the plant have been reported to exhibit antibacterial and antifungal activities. Previous phytochemical studies on the plant yielded terpenoid, sterols and flavonoids. The aim of the present study was to determine the analgesic activity Conyza floribunda extracts. Methanol, DCM and $n$-hexane extracts of the plant were subjects to toxicity, hot plate latency and acetic acid induced-writhing tests using Swiss Albino Mice. The plant extract showed analgesic activity in both hot plate latency and acetic acid induced-writhing tests. The extracts significantly increased the response time in the animals compared to the negative control. In the hot plate latency test, the analgesic activity of the extracts and that of morphine rose over time to peak at 90 minutes and then decreased afterwards. In the acetic acid-induces writhing test, administration of the plant extracts significantly reduced the number of abdominal contractions compared to the negative control. The percentage inhibitions of abdominal contractions were $67.2,46.5$ and 39.4 for methanol, DCM and $n$-hexane extracts respectively. The findings from this study have confirmed the folkloric information that extracts from $C$. floribunda have analgesic properties. We therefore recommend the extracts from the plant for use in pain management. Further studies should be carried out to isolate and characterize the analgesic principles from the plant.
\end{abstract}

Keywords: Conyza floribunda, Toxicity test, Analgesic activity, Hot plate test, Writhing test

DOI: $10.7176 / \mathrm{JNSR} / 12-12-01$

Publication date:June $30^{\text {th }} 2021$

\section{Introduction}

Traditional medicine still plays an important role in meeting the primary healthcare needs of a large proportion of population in Africa (WHO, 2014; Jeruto et al. 2017; Opiyo 2021; Opiyo et al. 2021). Previous studies have shown the potential of plants extracts in managing infections as well as in controlling pests (Ochieng et al. 2013; Ochung' et al. 2015, 2018; Makenzi et al. 2019a, 2019b; Opiyo 2020a, 2020b, 2020c). Plants have been reported to produce secondary metabolites some of which are active against infectious pathogens (Manguro et al. 2010a, 2010b; Njoroge and Opiyo, 2019a, 2019b, Ndirangu et al. 2020, 2020b). Synthetic anti-infective drugs are currently available in the market. However, continued search for novel bioactive compounds is unavoidable as most of the currently available drugs have demonstrated limitations in terms of side effects and drug resistance (WHO 2014). In recent years, many researchers have focused on authenticating the efficacy of medicinal plant extracts through in-vivo and in-vitro experiments (Opiyo 2011, 2019; Opiyo et al. 2015, 2017; Ochieng et al. 2017; Kuria and Opiyo 2020). Such studies have resulted in to the identification of important biologically active terpenoids, alkaloids, steroids, flavonoids and quinones (Manguro et al. 2009; Opiyo et al. 2011a, 2011b). The bioactive compounds derived from natural origin represent an important source of drugs in the process of developing new pharmacologically active compounds. The genus Conyza (Asteraceae) comprises of about fifty species, which are mainly found in tropical and subtropical regions (Agnew and Agnew 1994). Extracts from Conyza species are traditionally used to treat a wide range of infections (Kokwaro 2009; Shah et al. 2013; Viteri et al. 2020). Extracts from Conyza floribunda have been reported to exhibit antibacterial and antifungal activities (Opiyo et al. 2010a, 2010b, 2010c; Kowero et al. 2018). Previous phytochemical studies on the plant yielded terpeneoids, sterols and flavonoids (Opiyo et al. 2009, 2010a). Studies on other Conyza species have led to the isolation of secondary metabolites with antimicrobial, anti-inflammatory, antitumor and antioxidants activities (Shah et al. 2013, Aiyelaagbe et al. 2016; Viteri et al. 2020). The present study reports the analgesic activity of $n$-hexane, dichloromethane and $\mathrm{MeOH}$ extracts of Conyza floribunda.

\section{Materials and Methods}

2.1 Collection of Plant Material and Solvent Extraction

Conyza floribunda whole plant was collected from uncultivated farms in Maseno. The plant specimen was authenticated at the National Museum of Kenya, where a voucher specimen (2005/06/01/SAO/CHEMMK) was 
deposited. The whole plant was dried under the shade and reduced to powder using a hand mill. One $\mathrm{kg}$ of the powdered plant material was sequentially extracted with n-hexane, dichloromethane and methanol by soaking in the solvent for seven days with occasional shaking. The mixture was thereafter filtered and concentrated in-vacuo to afford 18, 24 and $35 \mathrm{~g}$ of n-hexane, dichloromethane and methanol extracts respectively.

\subsection{Test Animals}

Swiss albino mice (age: 4-5 weeks old, weight: 19-25 g) of either sex were used in the study. Animals were kept in cages in standard temperature-regulated rooms with air-cooling and 12 hours light and dark cycle and had free access to water and standard laboratory diet. They were allowed to acclimatize to the laboratory conditions and trained to adapt to restrainer for a period of one week before the experiments were conducted. Food was withdrawn 12 hours prior to drug administration until the completion of the study (Santenna et al. 2019). All experiments were conducted in accordance with animal use ethics as accepted internationally (C.I.O.M.S, 1985).

\subsection{Toxicity test}

Toxicity test was done according to Fyad et al. (2020). Ten batches of six (6) mice were used for testing the aqueous extract of $C$. floribunda. Doses of 50,100 and $150 \mathrm{mg} / \mathrm{kg}$ of the extract were administered intraperitoneally (i.p) to the test animals. The control batch was administered with normal saline at the rate of 10 $\mathrm{ml}$ per kg body weight. The animals were then observed for 2 hours to record immediate signs and behavior following intoxication, and monitored against the control group. After the 2 hours, the mice were given food and water, followed by two observation periods (one for 24 hours and one for 48 hours).

\subsection{Hot plate latency test}

The method of Lanhers et al. (1992) and Williamson et al. (1996) was used. Mice were placed on a hot plate maintained at temperature of $50 \pm 1^{0} \mathrm{C}$. The time taken for either paw licking or jumping (pain reaction time) by each mouse was recorded. Mice that showed initial nociceptive response within 20 seconds were selected and used for the study. The mice were then divided into 5 groups of 6 mice per group. Group I served as negative control and received $10 \mathrm{ml}$ per $\mathrm{kg}$ per oral (p.o) of $0.8 \%$ normal saline water which also doubled as a vehicle. Groups II, III and IV received $100 \mathrm{mg} / \mathrm{kg}$ (p.o) of n-hexane, DCM and $\mathrm{MeOH}$ extracts respectively. Group V received Morphine $0.5 \mathrm{mg}$ per $\mathrm{kg}$ (subcutaneous, s.c) to act as positive control. Latency was recorded after 30, 60, 90 and $120 \mathrm{~min}$ following oral administration of extracts $(100 \mathrm{mg} / \mathrm{kg})$, normal saline $(10 \mathrm{ml} / \mathrm{kg})$ and subcutaneous administration of morphine $(0.5 \mathrm{mg} / \mathrm{kg})$. A post-treatment cut off time of $30 \mathrm{~s}$ was used to avoid paw tissue damage (Sheikh et al, 2016).

\subsection{Acetic acid-induced writhing test}

The test was conducted as described by Koster et al. (1959) with some modifications. Swiss albino mice fasted overnight were divided into 5 groups of 6 mice each. The first group served as a negative control and was received $10 \mathrm{ml} / \mathrm{kg}$ i.p normal saline. Groups II, III, and IV received $100 \mathrm{mg} / \mathrm{kg}$ (p.o) of n-hexane, DCM and MeOH extracts respectively. Group V was received diclofenac $10 \mathrm{mg} / \mathrm{kg}$ body weight (p.o) to act as positive control. Sixty minutes later, each mouse was injected with acetic acid $(0.6 \%, \mathrm{v} / \mathrm{v}$ in normal saline, $10 \mathrm{~mL} / \mathrm{kg}$, i.p). The number of abdominal construction for each mouse was counted five minutes after injection of acetic acid for a period of 20 minutes. Percentage inhibition of writhing was calculated using the formula below.

\section{Number of writhes (control) - Number of writhes (treatment) $\times 100$ \\ Number of writhes (control)}

The results of the experiments were expressed as mean \pm SD $(n=6)$. Data obtained from the experiments were subjected to analysis of variance (ANOVA) and means were separated by least significant difference (LSD) at five percent significant level.

\section{Results and Discussion}

3.1 Toxicity effect of extracts

Signs of change, intoxication and sudden death in the test animals were monitored for 2 hours after administration (i.p) of the plant extracts and the control. The mice were observed further at 24 and 48 hours to determine the delayed effects of administering the doses of the test extract of $C$. floribunda and the results were as recorded in Table 1. The results show that doses of the plant extracts of 50,100 and $150 \mathrm{mg}$ per kg body weight did not cause any noticeable hypoactivity, drowsiness or tachycardia the mice. Furthermore, no mortality was observed during the duration of the test. This showed that the extracts were safe to the mice. 
Table 1. Results of toxicity test of Conyza floribunda extracts

\begin{tabular}{|c|c|c|c|c|c|}
\hline Treatment & Dose (mg/kg) & Symptoms & & Mortality \\
\hline $0.8 \%$ normal saline & $\mathbf{1 0}$ & Hypoactivity & Drowsiness & Tachycardia & 0 \\
\hline$n$-Hexane extract & $\mathbf{5 0}$ & - & - & - & $\mathbf{0}$ \\
\hline$n$-Hexane extract & $\mathbf{1 0 0}$ & - & - & - & $\mathbf{0}$ \\
\hline$n$-Hexane extract & $\mathbf{1 5 0}$ & - & - & - & $\mathbf{0}$ \\
\hline DCM extract & $\mathbf{5 0}$ & - & - & - & $\mathbf{0}$ \\
\hline DCM extract & $\mathbf{1 0 0}$ & - & - & - & $\mathbf{0}$ \\
\hline DCM extract & $\mathbf{1 5 0}$ & - & - & - & $\mathbf{0}$ \\
\hline MeOH extract & $\mathbf{5 0}$ & - & - & - & $\mathbf{0}$ \\
\hline MeOH extract & $\mathbf{1 0 0}$ & - & - & - & $\mathbf{0}$ \\
\hline MeOH extract & $\mathbf{1 5 0}$ & - & - & - & $\mathbf{0}$ \\
\hline
\end{tabular}

- : No sign; + : High sign

\subsection{Hot Plate Test}

Results from the hot plate test show that $C$. floribunda extracts at a concentration of $100 \mathrm{mg} / \mathrm{kg}$ body weight significantly increased the response time in the animals at a time dependent manner (Table 2). The pretreatment latency of the plant extracts $(100 \mathrm{mg} / \mathrm{Kg})$ were comparable to that of morphine $(3.2 \pm 0.14)$ at the zero minute indicating that the extracts were more or less as effective as the standard analgesic drug used. The analgesic effect of the test materials and that of morphine rose over time to peak at 90 minutes and then decreased afterwards. Methanol extract was the most effective followed by DCM and n-hexane extracts and showed latency of 15.7, 13.2 and $10.4 \mathrm{sec}$ respectively at 90 minutes. However, the analgesic effect of the plant extracts was significantly $(p<0.05)$ lower than those produced by morphine in the same tests at 30, 60, 90 and 120 minutes.

\subsection{Effect of C. floribunda extracts on acetic acid-induced writhing}

The analgesic effect of $C$. floribunda extracts was also tested using the acetic acid-induced writhing method (Table 2 ). The control group which received normal saline showed abdominal contraction after injected with acetic acid. The average number of abdominal contraction in the control group was $68.2 \pm 2.2$, with a percentage inhibition of zero (0) in duration of 20 minutes. Administration of the plant extracts at a dose of $100 \mathrm{mg} / \mathrm{kg}$ body weight significantly reduced the number of abdominal contractions compared to the negative control. Methanol extract was significantly more effective followed by DCM and n-hexane extracts in that order. The percentage inhibitions were $67.2,46.5$ and 39.4 for methanol, DCM and n-hexane extracts respectively and were significantly lower than percentage inhibitions exhibited by diclofenac which was used as a positive control.

The two methods (hot plate and acetic acid-induced writhing) used in this study show that $C$. floribunda extracts have analgesic activity. The results are in agreement with previous studies which also showed that extracts from Conyza species have analgesic activity (Asongalem et al. 2004; Ovalle-Magallanes et al. 2015; Ishfaq et al. 2018). However, this is the first report on the analgesic activity of $C$. floribunda. The toxicity test gave negative results thus indication that the extracts are not toxic. In both tests, the effectiveness of the extracts in the analgesic tests were in the order of methanol $>$ DCM $>$ n-hexane, which suggests that the analgesic principles in the plant are polar and therefore could be extracted using polar solvents. In traditional medicine, water which is a polar solvent is used as the extraction solvent. 
Table 2. Effects of extracts on hot plate-induced pain and acetic acid-induced writhing in mice

\begin{tabular}{|c|c|c|c|c|c|c|c|}
\hline & Pre-treatment & \multicolumn{4}{|c|}{ Post- treatment latency (sec) } & Total no. & $\%$ \\
\hline Treatment & $0 \mathrm{~min}$ & $30 \mathrm{~min}$ & $60 \mathrm{~min}$ & $90 \mathrm{~min}$ & $120 \mathrm{~min}$ & & \\
\hline $\begin{array}{l}\text { Vehicle }(0.8 \% \\
\text { normal saline })\end{array}$ & $3.2 \pm 0.10$ & $\begin{array}{c}3.4 \\
\pm 0.13\end{array}$ & $\begin{array}{c}3.6 \pm \\
0.11\end{array}$ & $\begin{array}{c}3.7 \pm \\
0.10\end{array}$ & $\begin{array}{c}3.7 \pm \\
0.16\end{array}$ & $68.2 \pm 2.2$ & 0.0 \\
\hline $\begin{array}{c}n \text {-Hexane extract } \\
(100 \mathrm{mg} / \mathrm{kg})\end{array}$ & $3.1 \pm 0.15$ & $\begin{array}{c}4.8 \pm \\
0.12\end{array}$ & $\begin{array}{c}13.6 \pm \\
0.16\end{array}$ & $\begin{array}{c}10.4 \pm \\
0.14\end{array}$ & $\begin{array}{l}6.4 \pm \\
0.23\end{array}$ & $41.3 \pm 1.8$ & 39.4 \\
\hline $\begin{array}{c}\text { DCM extract (100 } \\
\mathrm{mg} / \mathrm{kg})\end{array}$ & $3.3 \pm 0.11$ & $\begin{array}{l}6.9 \pm \\
0.28\end{array}$ & $\begin{array}{c}16.4 \pm \\
0.13\end{array}$ & $\begin{array}{c}13.2 \pm \\
0.15\end{array}$ & $\begin{array}{l}7.6 \pm \\
0.11\end{array}$ & $35.1 \pm 2.1$ & 46.5 \\
\hline $\begin{array}{c}\mathrm{MeOH} \text { extract (100 } \\
\mathrm{mg} / \mathrm{kg})\end{array}$ & $3.6 \pm 0.10$ & $\begin{array}{l}6.1 \pm \\
0.12 \\
\end{array}$ & $\begin{array}{c}14.3 \\
\pm 0.21 \\
\end{array}$ & $\begin{array}{c}15.7 \pm \\
0.22 \\
\end{array}$ & $\begin{array}{l}8.5 \pm \\
0.21 \\
\end{array}$ & $22.4 \pm 1.1$ & 67.2 \\
\hline $\begin{array}{c}\text { Morphine }(0.5 \\
\mathrm{mg} / \mathrm{kg})\end{array}$ & $3.2 \pm 0.14$ & $\begin{array}{l}8.1 \pm \\
0.16 \\
\end{array}$ & $\begin{array}{c}24.3 \pm \\
0.16 \\
\end{array}$ & $\begin{array}{c}27.2 \pm \\
0.17 \\
\end{array}$ & $\begin{array}{c}16.3 \pm \\
0.15 \\
\end{array}$ & NT & \\
\hline $\begin{array}{c}\text { Diclofenac (10 } \\
\mathrm{mg} / \mathrm{kg})\end{array}$ & NT & NT & NT & NT & NT & $12.7 \pm 1.3$ & 81.4 \\
\hline LSD, $\mathrm{P} \leq 0.05$ & & & 0.2 & & & & \\
\hline
\end{tabular}

Values are mean $\pm \mathrm{SD}(\mathrm{n}=6) ; \mathrm{NT}=$ Not tested

\section{Conclusion}

The findings from this study have confirmed the folkloric information that extracts from C. floribunda have analgesic properties. Use of plant extracts to treat infections is more preferred especially in rural set up in Africa since plant extracts are readily available and renewable, and chances of insects developing resistance are negligible.

We therefore recommend the continued use of the plant in pain management. Further studies should be carried out to isolate and characterize the bioactive principles from the plant.

\section{Acknowledgement}

The authors are grateful to the National Commission for Science, Technology and Innovation (NACOSTI), Kenya for financial support.

\section{Disclosure}

Authors declare that there is no conflicts of interest in this work.

\section{References}

Agnew, A.D.Q. \& Agnew, S. (1994). Kenya Upland Wild Flowers. East African Natural History, Nairobi, Kenya. Aiyelaagbe, O.O., Oguntoye, S.O., Hamid, A.A., Ogundare, A.M., Ojo, D.B., Ajao, A. \& Owolabi, N.O. (2016). GC-MS analysis, antimicrobial and antioxidant activities of extracts of the aerial parts of Conyza sumatrensis. J. Appl. Sci. Environ. Manage, 20 (1), 103-110.

Asongalem, E.A., Foyet, H.S., Ngogang, J., Folefoc, G.N., Dimo, T. \& Kamtchouing, P. (2004). Analgesic and anti-inflammatory activities of Erigeron floribundus. J. Ethnopharmacol. 91, 301-308. doi: 10.1016/j.jep.2004.01.010. PMID: 15120453.

Bukhari, I.A., Sheikh, S.A., Shaikh, N.A., Assiri, A.M. \& Gilani, A.H. (2018). Peripheral analgesic and antiinflammatory activities of the methanolic extracts of Conyza bonariensis and its fractions in rodents models. International Journal of Pharmacology, 14: 144-150.

Council for International Organisation of Medical Sciences (1985). 1211 Geneva,Switzerland.

Fyad, K., Belboukhari, N., Hadj-Khelil, A., \& Sekkoum, K. (2020). Analgesic and anti-inflammatory activity of aqueous extract of Bubonium graveolens. Biomedical Research and Therapy, 7(9), 4002-4009. https://doi.org/10.15419/bmrat.v7i9.632

Jeruto, P., Arama, P., Anyango, B., Nyunja, R.A., Taracha, C. \& Opiyo, S.A. (2017). Morphometric study of Senna didymobotrya (Fresen.) H. S. Irwin and Barneby in Kenya. Journal of Natural Sciences Research, 7 (6), $54-$ 69.

Kokwaro, J.O. (2009). Medicinal Plants of East Africa. University of Nairobi Press, Nairobi, Kenya.

Koster, R., Anderson, M. \& De-Beer EJ. (1959). Acetic acid for analgesic screening. Fed Proc 18, $412-418$.

Kowero, E.E., Leweri, C. \& Chacha, M. (2018). In vitro antifungal activity of Embelia schimperi (Vatke) and Conyza floribunda. International Journal of Biosciences, 13 (3), 45-50.

Kuria, K.M. \& Opiyo, S.A. (2020). Characterization of immunogenic soluble crude proteins from Biomphalaria Pfeifferi against Schistosoma mansoni. Journal of Natural Sciences Research 10(12), 28-34. 
DOI: $10.7176 / \mathrm{JNSR} / 10-12-03$.

Lanhers, M.C., Fleurentin, J., Mortier, F., Vinche, A. \& Younos, C. (1992). Anti-inflammatory and analgesic effects of an aqueous extract of Harpagophytum procumbens. Planta Med 58, 117-123.

Makenzi, A.M., Manguro, L.A.O., Owuor, P.O. \& Opiyo, S.A. (2019a). Chemical constituents of Ocimum Kilimandscharicum Guerke acclimatized in Kakamega Forest, Kenya. Bulletin of the Chemical Society of Ethiopia, 33(3), 527-539. DOI: https://dx.doi.org/10.4314/bcse.v33i3.13.

Makenzi, A.M., Manguro, L.O.A, Owuor, P.O. \& Opiyo, S.A. (2019b). Flavonol glycosides with insecticidal activity from methanol extract of Annona mucosa Jacq. leave. Trends in Phytochemical Research, 3(4), $287-$ 296.

Manguro, L, Ogur, J. \& Opiyo, S. (2010b). Antimicrobial constituents of Conyza floribunda. Webmed Central Pharmacology, 1(9), WMC00842.

Manguro, L.O.A., Opiyo, S.A., Asefa, A., Dagne, E. \& Muchori, W.P. (2010a). Chemical constituents of essential oils from three Eucalyptus species acclimatized in Ethiopia and Kenya. Journal of Essential Oil Bearing Plants, 13(5), 561-567. https://doi.org/10.1080/0972060X.2010.10643863.

Manguro, L.A.O., Opiyo, S.A., Herdtweck, E., Lemmen, P. (2009). Triterpenes of Commiphora holtziana Oleogum resin. Canadian Journal of Chemistry 87(8): 1173-1179.

Ndirangu, E.G., Opiyo, S.A. \& Ng'ang'a, M.W. (2020a). Chemical composition and repellency of Nigella sativa L. seed essential oil against Anopheles gambiae sensu stricto. Trends in Phytochemical Research, 4(2), 7784.

Ndirangu, E.G., Opiyo, S.A. \& Ng'ang'a, M.W. (2020b). Repellent properties of compounds and blends from Nigella sativa seeds against Anopheles gambiae. Basic Sciences of Medicine, 9(1), 1-7. doi:10.5923/j.medicine.20200901.01.

Njoroge, P.W. \& Opiyo, S.A. (2019a). Antimicrobial activity of root bark extracts of Rhus natalensis and Rhus ruspolii. Basic Sciences of Medicine, 8(2), 23-28. doi:10.5923/j.medicine.20190802.01.

Njoroge, P.W. \& Opiyo, S.A. (2019b). Some antibacterial and antifungal compounds from root bark of Rhus natalensis. American Journal of Chemistry, 9(5), 150-158. doi:10.5923/j.chemistry.20190905.03.

Ochieng, C.O., Ishola, I., Opiyo, S.A., Manguro, L.O.A., Owuor, P.O. \& Wong, K.C. (2013). Phytoecdysteroids from the stem bark of Vitex doniana and their anti-inflammatory effects. Planta Medica, 79, 52-59. DOI:10.1055/s-0032-1327880.

Ochieng, C.O., Opiyo, S.A., Mureka, E.W. \& Ishola I.O. (2017). Cyclooxygenase inhibitory compounds from Gymnosporia heterophylla aerial parts. Fitoterapia 119, 168-174. DOI: 10.1016/j.fitote.2017.04.015

Ochung', A.A., Manguro, L.A.O., Owuor, P.O., Jondiko, I.O., Nyunja, R.A., Akala, H., Mwinzi, P. \& Opiyo, S.A. (2015). Bioactive carbazole alkaloids from Alysicarpus ovalifolius (Schumach). Korean Society for Applied Biological Chemistry, 58(6), 839-846. https://doi.org/10.1007/s13765-015-0100-4

Ochung', A.A., Owuor, P.O., Manguro, L.A.O., Ishola, O.I., Nyunja, R.A., Ochieng, C.O., \& Opiyo, S.A. (2018). Analgesics from Lonchocarpus eriocalyx Harms. Trends in Phytochemical Research, 2(4), 253-260.

Opiyo, S.A. (2011). Evaluation of efficacy of selected plant extracts in the management of Fungal and bacterial diseases which affect sweet potato. Unpublished $\mathrm{PhD}$ thesis, Maseno University, Kenya.

Opiyo, S.A. (2019). A review of ${ }^{13} \mathrm{C}$ NMR spectra of drimane sesquiterpenes. Trends in Phytochemical Research, $3(3), 147-180$.

Opiyo, S.A. (2020a). Insecticidal activity of Ocimum Suave Willd extracts and compounds against Sitophilus Zeamais Motschulsky. Basic Sciences of Medicine, 2020, 9(2), 32-37. DOI: 10.5923/j.medicine.20200902.03.

Opiyo, S.A. (2020b). Evaluation of Warburgia ugandensis extracts and compounds for crop protection against Prostephanus truncates. Advances in Analytical Chemistry, 10(2), 15-19. DOI: 10.5923/j.aac.20201002.01

Opiyo, S.A. (2020c). Insecticidal activity of Elaeodendron schweinfurthianum extracts and compounds against Sitophilus zeamais Motschulsky. American Journal of Chemistry, 10(3), 39-44. doi:10.5923/j.chemistry.20201003.01

Opiyo, S.A. (2021). Repellent effects of Ocimum suave extracts and compounds against Prostephanus truncatus horn. American Journal of Chemistry 11(2): 23-27, DOI: 10.5923/j.chemistry.20211102.01.

Opiyo, S.A., Manguro, L.A.O., Akinyi, D., Ochung, A.A. \& Ochieng C.O. (2015). Biopesticidal extractives and compounds from Warburgia ugandensis against maize weevil (Sitophilus zeamais). Natural Products, 5(4), 236-243. DOI: $10.2174 / 2210315505666150916000539$.

Opiyo, S.A., Manguro, L.A.O., Owuor, P.O. \& Ateka, E.M. (2017). Triterpenes from Elaeodendron schweinfurthianum and their antimicrobial activities against crop pathogens. American Journal of Chemistry, 7 (3), 97-104. doi:10.5923/j.chemistry.20170703.03

Opiyo, S.A., Manguro, L.O.A., Ogur, J.A. \& Wagai, S.O. (2010a). Bioactive constituents of Conyza floribunda. Research Journal of Pharmacology, 4 (3), 55-59.

Opiyo, S.A., Owuor, P.O., Manguro, L.O.A., Ateka, E., Miano, D.W. (2010b). Development of a PCR technique 
for simultaneous detection of sweet potato chlorotic stunt virus and sweet potato feathery mottle. Journal of Plant Pathology, 92(2): 353-356.

Opiyo, S.A., Owuor, P.O., Manguro, L.O.A., Ateka, E.M., Karuri, H.W. (2010c). Survey of sweet potato viruses and detection of cucumber mosaic virus in western Kenya. Journal of Plant Pathology, 92(3) 795-799.

Opiyo, S.A., Manguro, L.O.A., Okinda-Owuor, P., Ateka, E.M. \& Lemmen P. (2011a). 7-alpha Acetylugandensolide and antimicrobial properties of Warburgia ugandensis extracts and isolates against sweet potato pathogens. Phytochemistry Letters, 4, 161-165. https://doi.org/10.1016/j.phytol.2011.02.007

Opiyo, S.A., Manguro, L.O.A., Owuor, P.O., Ochieng, C.O., Ateka, E.M. \& Lemmen P. (2011b). Antimicrobial compounds from Terminalia brownii against sweet potato pathogens. Natural Products, 1, 116-120. DOI:10.2174/2210316311101020116

Opiyo, S.A., Njoroge, P.W., Ndirangu, G.E. \& Kuria, K.M. (2021). A review of biological activities and phytochemistry of Rhus species. American Journal of Chemistry, 11(2), 28-36. DOI: 10.5923/j.chemistry.20211102.02

Opiyo, S.A., Ogur, J.A., Manguro, L.O.A., Itietze, L.F. \& Schuster, H. (2009). A new sterol diglycoside from Conyza floribunda. South African Journal of Chemistry, 62, 163-167.

Ovalle-Magallanes, B.M., Déciga-Campos, M. \& Mata, R. (2015). Antinociceptive and hypoglycaemic evaluation of Conyza filaginoides (D.C.) Hieron Asteraceae. J Pharm Pharmacol, 67(12), 1733-43. doi: 10.1111/jphp.12477. Epub 2015 Sep 26. PMID: 26408418.

Santenna, C., Kumar, S., Balakrishnan, S., Jhaj, R. \& Ahmed, S.N. (2019). A comparative experimental study of analgesic activity of a novel non-steroidal anti-inflammatory molecule - zaltoprofen, and a standard drug piroxicam, using murine models. Journal of Experimental Pharmacology, 11, 85-91.

Shah, N.Z., Muhammad, N., Azeem, S., Khan, A.Z., Samie, M. \& Khan, H. (2013). Antimicrobial and phytotoxic properties of Conyza bonariensis. Pharmacy and Pharmacology Research, 1(1), 8-11.

Sheikh, B.Y., Zihad, S.N.K., Sifat, N., Uddin, S.J., Shilpi, J.A., Hamdi, O. A. (2016). Comparative study of neuropharmacological, analgesic properties andphenolic profile of Ajwah, Safawy and Sukkari cultivars of date palm (Phoenix dactylifera). Orient. Pharm. Exp. Med. 16, 175-183. doi: 10.1007/s13596-016-0239-5.

Viteri, R., Peñarreta, J., Quijano-Avilés, M., Barragán, A., Chóez-Guaranda, I. \& Manzano, P. (2020). Antioxidant activity and GC-MS profile of Conyza bonariensis L. leaves extract and fractions. Rev. Fac. Nac. Agron. Medellín, 73(3), 9305-9313.

Williamson, E.M., Okpako, D.T. \& Evans, F.J. (1996). Pharmacological Methods in Phytotherapy Research. Volume I. Selection, Preparation and Pharmacological Evaluation of Plant Materials. John Wiley: Chichester, 184-186.

World Health Organization, WHO, 2014. Traditional Medicine Strategy 2014-2023, 2014. DOI: http:llapps.who.int7irislbitstream7106651924551-119789241506090eng.pdf?ua=1. 